\title{
Jurnal
}

p-ISSN 2621 - 797X ; e-ISSN 2746-6841 DOI:10.32493

Jurnal Disrupsi Bisnis, Vol. 4, No. 2, Maret 2021 (165-173)

http://openjournal.unpam.ac.id/index.php/DRB/index

\section{Pengaruh Rekrutmen Dan Seleksi Karyawan Terhadap Kinerja Karyawan PT. Telkom Akses Jakarta Barat}

\author{
N.Lilis Suryani ${ }^{1 *}$, Asep Sulaeman ${ }^{2}$ \\ 1,2 Fakultas Ekonomi, Universitas Pamulang; dosen00437@umpam.ac.id*
}

Received 26 Maret 2021| Revised 27 Maret 2021 | Accepted 27 Maret 2021

*Korespondensi Penulis

\begin{abstract}
Abstrak
Penelitian ini untuk mengetahui pengaruh rekrutmen dan seleksi karyawan terhadap kinerja pegawai PT. Telkom Akses Jakarta. Metode penelitian menggunakan pendekatan deskriptif kuantitatif dengan sampel 70 responden. Analisis data yang digunakan adalah analisis dalam bentuk uji regresi linear berganda. Hasil penelitian menunjukkan bahwa secara parsial dan simultan, variabel rekrutmen dan seleksi karyawan berpengaruh terhadap kinerja PT. Telkom Akses. Hasil uji parsial pengaruh rekrutmen terhadap kinerja diperoleh nilai $t$-hitung 2,692 > t- 1,960 dan nilai signifikan 0,009<0,05. Hasil uji parsial pengaruh seleksi karyawan terhadap kinerja diperoleh nilai t-hitung 19,351>t-tabel 1,960 dan nilai signifikan 0,000<0,05. Hasil uji simultan (Uji F) diperoleh nilai Fhitung 196,432 dengan nilai signifikasi adalah $0,000<0,05$, yang berarti secara parsial dan secara simultan rekrutmen dan seleksi karyawan berpengaruh terhadap kinerja karyawan.
\end{abstract}

Kata Kunci: Rekrutmen; seleksi karyawan; kinerja

\begin{abstract}
This study is to determine the effect of employee recruitment and selection on the performance of employees of PT. Telkom Access Jakarta. The research method used a quantitative descriptive approach with a sample of 70 respondents. The data analysis used is analysis in the form of multiple linear regression test. The results showed that partially and simultaneously, the variable recruitment and selection of employees had an effect on the performance of PT. Telkom Access. The partial test results of the effect of recruitment on performance obtained the $t$-count value of 2.692>t-1.960 and a significant value of $0.009<0.05$. The partial test results of the effect of employee selection on performance obtained the t-count value 19.351>t-table 1.960 and a significant value of $0.000<0.05$. The results of the simultaneous test (F test) obtained the Fcount value of 196.432 with a significance value of $0.000<0.05$, which means that partially and simultaneously recruitment and selection of employees have an effect on employee performance.
\end{abstract}

Keywords: Recruitment; employee selection; performance

\section{PENDAHULUAN}

Sumber daya manusia dalam suatu organisasi merupakan penentu yang sangat penting bagi keefektifan berjalannya kegiatan didalam organisasi. Sumber daya manusia menjadi perencana, pelaku, dan penentu terwujudnya tujuan organisasi. Maju dan mundurnya perusahaan sangat ditentukan oleh peran aktif setiap sumber daya manusia yang ada dalam perusahaan tersebut. Perusahaan juga dituntut untuk mampu mengelola sumber daya manusia yang dimiliki, sehingga dapat mencapai tujuan perusahaan dengan efektif dan efisien. 
Dalam era perdagangan bebas semua organisasi dituntut meningkatkan kualitas sumber daya manusia yang proaktif terhadap perubahan yang terjadi. Dan dalam hal ini Indonesia sebagai salah satu Negara yang berkembang harus siap untuk menghadapi era globalisasi sebagai sebuah kesempatan bukan ancaman. Maka perusahaan-perusahaan di Indonesia harus mempersiapkan diri untuk menghadapinya, terutama dengan mengembangkan sumber daya manusia yang dimiliki. Hal tersebut dilakukan untuk menghadapi persaingan yang semakin meningkat.

Manajemen sumber daya manusia dipandang sebagai peranan yang cukup penting di ranah industri, apa yang dilakukan oleh manajer sumber daya manusia menggambarkan bagaimana aktifasi pengelolaan sumber daya manusiadi lingkungan perusahaan. Menurut Widodo (2015:2), manajemen sumber daya manusia adalah suatu proses yang mencakup evaluasi terhadap kebutuhan sumber daya manusia, mendapatkan orang-orang untuk memenuhi kebutuhan itu, dan mengoptimasikan pendayagunaan sumber daya yang penting tersebut dengan cara memberikan insentif dan penugasan yang tepat, agar sesuai dengan kebutuhan dan tujuan organisasi dimana sumber daya manusia itu berada.

Salah satu hal yang terpenting dalam aktivitas sumber daya manusia adalah tentang rekrutmen dan seleksi. Proses rekrutmen dan seleksi merupakan hal yang sangat vital dalam sebuah perusahaan. Keakuratan dalam rekrutmen dapat meningkatkan efektivitas dan efisiensi operasional perusahaan. Selain itu, proses rekrutmen dan seleksi yang baik juga dapat mempengaruhi kinerja karyawan pada sebuah perusahaan. PT. Telkom Akses JakartaBarat merupakan salah satu anak perusahaan Telkom yang bergerak di dalam bisnis penyediaan layanan konstruksi dan pengelolaan infrastruktur jaringan. Dimana perusahaan harus menyiapkan sumber daya manusia yang handal dan kompeten yang siap untuk melayani pelanggan, sehingga memberikan kepuasan pelayanan kepada pelanggan yang menggunakan jasa perusahaan. Oleh karena itu, perusahaan perlu melaksanakan rekrutmen dan seleksi yang baik sehingga sumber daya manusia yang dihasilkan dapat menjadi salah satu faktor kunci keberhasilan untuk mencapai tujuanperusahaan. Menurut Malthis dalam Widodo (2015:56), rekrutmen merupakan suatu proses pengumpulan sejumlah pelamar yang memiliki kualifikasi yang sesuai dengan yang dibutuhkan perusahaan, untuk dipekerjakan di dalam perusahaan.

Menurut Casio dan Munandar dalam Yani (2012:61), menyatakan bahwa rekrutmen adalah suatu proses penerimaan calon tenaga kerja untuk bekerja dalam suatu organisasi atau perusahaan. Prosesnya dimulai saat akan kebutuhan merekrut karyawan baru dinyatakan hingga lamaran merekaditerima. Sedangkan Mila Badriyah (2015:88), mengartikan bahwa rekrutmen merupakan proses mendapatkan sejumlah calon tenaga kerja yang berkualitas untuk jabatan/pekerjaan utama dilingkungan perusahaan. Adapun manfaat dari rekrutmen adalah memiliki fungsi sebagai "The Right Man On The Place and $J o b$ ", dimana hal ini menjadi pegangan bagi para manajer dalam menempatkan tenaga kerja yang ada perusahaan.

Pelaksanaan rekrutmen terhadap calon karyawan dimaksudkan agar perusahaan dapat memperoleh karyawan yang berkualitas dan mampu merealisasikan tujuan perusahaan. Sedangkan kegagalan dalam melakukan rekrutmen dan seleksi akan mempengaruhi kinerja karyawan yang selanjutnya menjadi penghambat bagi proses pencapaian tujuan perusahaan. Sistem rekrutmen dan penempatan kerja yang dilakukan dengan tepat dan sesuai dengan kebutuhan bertujuan agar tercapainya tujuan perusahaan serta kesulitan dalam mencari dan melatih karyawan dapat dihindari. Terkadang proses rekrutmen yang dijalani tidakberjalan sesuai yang diharapkan. Jumlah calon tenaga kerja yang datang melamar sedikit, sehingga hal ini mempengaruhi kualitas tenaga kerja yang akan diseleksi nantinya. Disamping itu, terkadang kualifikasi pelamar yang diperoleh tidak sesuai dengan yang diharapkan. Berikut adalah tabel perekrutan karyawan dari tahun 2016 sampai dengan tahun 2019 padaPT. Telkom Akses JakartaBarat.

Tabel 1. Jumlah Pelamar, Karyawan yang dibutuhkan dan Perekrutan Karyawan Baru

Pada PT. Telkom Akses JakartaBarat tahun 2016 - 2019

\begin{tabular}{cccc}
\hline Tahun & Jumlah Pelamar & $\begin{array}{c}\text { Jumlah karyawan yang } \\
\text { dibutuhkan }\end{array}$ & $\begin{array}{c}\text { Jumlah karyawan } \\
\text { yang terealisasi }\end{array}$ \\
\hline 2016 & 41 & 22 & 22 \\
\hline 2017 & 52 & 35 & 35 \\
\hline 2018 & 58 & 20 & 17 \\
\hline 2019 & 63 & 37 & 25 \\
\hline Sumber: PT. Telkom Akses Jakarta Barat &
\end{tabular}

Dari tabel diatas dapat dilihat bahwa jumlah pelamar terus meningkat dari tahun ke tahun, 
sedangkan pelamar yang diterima hanya pada tahun 2016 dan 2017 saja yang sesuai dengan jumlah kebutuhan pada setiap divisi yang ada di PT. Telkom Akses JakartaBarat, akan tetapi pada tahun 2016 jumlah yang dibutuhkan 20 orang namun hanya 17 orang terealisasi, dan pada Tahun 2019 jumlah yang dibutuhkan 37 orang namun hanya 25 orang yang terealisasi, sehingga jumlah perekrutan karyawan tidak sesuai dengan kebutuhan tenaga kerja.

Dari proses rekrutmen, setelah itu perusahaan akan melaksanakan seleksi untuk memilih karyawan yang akan menjadi karyawan sesuai dengan kualifikasi yang memenuhi persyaratan dan sesuai dengan kebutuhan perusahaan untuk menempati posisi atau jabatan tertentu dalam perusahaan tersebut. Tujuan seleksi itu sendiri yakni untuk mendapatkan karyawan yang terampil dan memiliki keahlian sesuai dengan kebutuhan serta skor tertinggi dalam penilaian dan pertimbangan lainnya. Itu semua dilakukan semata-mata untuk mendapatkan karyawan yang siap atau diposisikan untuk mengisi jabatan tertentu.

Menurut Henry Simamora (2012:202), Seleksi adalah proses pemilihan dari sekelompok pelamar, atau orang-orang yang paling memenuhi kriteria seleksi untuk posisi yang tersedia berdasarkan kondisi yang ada saat ini yang dilakukan oleh perusahaan. Menurut Rivai (2011:159) menjelaskan bahwa seleksi adalah kegiatan dalam manajemen sumber daya manusia (SDM) yang dilakukan setelah proses rekrutmen selesaidilaksanakan. Sedangkan Menurut Malayu Hasibuan (2012:28) seleksi adalah suatu kegiatan pemiihan dan penentuan pelamar yang diterima atau ditolak untuk menjadi karyawan perusahaan. Hal ini berarti telah terkumpul sejumlah pelamar yang memenuhi syarat untuk kemudian dipilih mana yang dapat ditetapkan sebagai karyawan dalam suatu perusahaan. Proses pemilihan ini yang dinamakan dengan seleksi. Hal ini bertujuan agar perusahaan mendapatkan calon karyawan yang memiliki kemampuan yang lebih baik dari karyawan yang telahbekerjaterlebih dahulu. Seleksi juga dapat diartikan sebagai suatu proses pemilihan dari sekelompok pelamar orang atau orang- orang yang paling memenuhi kriteria.

Menurut Siswanto (dalam Muhammad Sandy, 2015:11) kinerja adalah prestasi yang dicapai oleh seseorang dalam melaksanakan tugas dan pekerjaan yang diberikan kepadanya. Sedangkan oeheriono (2012:95) mengartikan bahwa "Kinerja atau Performance merupakan gambaran mengenai tingkat pencapaian pelaksanaan suatu program kegiatan atau kebijakan dalam mewujudkan sasaran, tujuan, visi, dan misi organisasi yang dituangkan melalui perencanaan strategis suatuorganisasi”. Pelaksanaan seleksi yang berjalan masih belum sesuai kriteria yang telah ditetapkan oleh perusahaan dapat menyebabkan kinerja karyawan menurun dan dapat berdampak negatif terhadap perusahaan. Hal tersebut dapat dilihat dari semakin meningkatnya persentase ketidakhadiran karyawan dan masih ada prosedur perusahaan yang tidak berjalan sesuai dengan ketentuan.

PT. Telkom Akses Jakarta Barat merupakan salah satu anak perusahaan Telkom yang bergerak di dalam bisnis penyediaan layanan konstruksi dan pengelolaan infrastruktur jaringan. PT. Telkom Akses memiliki tenaga kerja yang handal dan mampu menjalankan tugas-tugas yang diberikan oleh perusahaansecara baik. Tenaga kerja yang handal akan diraih dengan cara melakukan seleksi karyawan yang tepat sesuai dengan spesifikasi jabatan tertentu, yang menyesuaikan syarat-syarat teretntu yang harus dimiliki pelamar, seperti latar belakang pendidikan, kemampuan yang dimiliki serta pengalaman kerja.

Mengingat sangat pentingnya proses seleksi bagi perusahaan, maka proses seleksi harus dilakukan denga obyektif. Karena dengan demikian proses seleksi akan berdampak pada perkembangan perusahaan kedepannya untuk memperoleh sumber daya manusia yang berkualitas di PT. Telkom Akses JakartaBarat sehingga setiap karyawan yang menempati jabatan tertentu dan sesuai dengan kualifikasi yang dibutuhkan oleh perusahaan.

Dari permasalahan yang ada, maka perlu mengkaji lebih dalam tentang "Pengaruh Rekrutmen dan Seleksi Karyawan Terhadap Kinerja Karyawan Pada PT. Telkom Akses Jakarta Barat”.

\section{Kinerja}

Menurut Malayu S.P Hasibuan (2012:94) kinerja adalah hasil kerja yang dicapai seseorang dalam melaksanakan tugas- tugas yang dibebankan kepadanya yang didasarkan atas kecakapan, pengalaman, kesungguhan, serta waktu. Menurut Armstrong dan Baron dalam Wibowo (2012:7) kinerja adalah hasil pekerjaan yang mempunyai hubungan kuat dengan tujuan strategiorganisasi, kepuasan konsumen, dan memberikan kontribusi pada ekonomi. Dengan demikian kinerja adalah tentang melakukan pekerjaan dan hasil dari pekerjaan tersebut. Sedarmayanti (2013:260) mengartikan bahwa kinerja merupakan hasil 
kerja yang dapat dicapai oleh seseorang atau sekelompok orang dalam organisasi, sesuai dengan wewenang dan tanggung jawab masing-masing, dalam rangka upaya mencapai tujuan organisasi.

Menurut Wirawan (2015:166) indikator dari kinerja terdiri dari: 1) Keterampilan kerja, yaitu penguasaan pegawai mengenal prosedur pelaksanaan tugas tugas jabatannya; 2) Kualitas pekerjaan, yaitu kemampuan pegawai menunjukan kualitas hasil kerja ditinjau dari segi ketelitian dan kerapian; 3) Tanggung jawab, yaitu kesediaan pegawai untuk melibatkan diri sepenuhnya dalam melaksanakan pekerjaannya dan menanggung konsekuensi akibat kesalahan/kelalaian dan kecerobohan pribadi dalam melaksanakan tugas; 4) Prakarsa, yaitu kemampuan pegawai dalam mengembangkan ide/gagasan dan tindakan yang menunjang penyelesaian tugas; 5) Disiplin, yaitu kesediaan pegawai dalam memenuhi peraturan perusahaan yang berkaitan dengan ketepatan waktu masuk/pulang kerja, jumlah kehadiran, dan keluar kantor bukan untuk urusan dinas; 6) Kerjasama, yaitu kemampuan pegawai untuk membina hubungan dengan pegawai lain dalam rangka menyelesaikan tugas; dan 7) Kuantitaspekerjaan, yaitu Kemampuan pegawai dalam menyelesaikan sejumlah hasil tugas setiap harinya.

\section{Rekrutmen}

Menurut Mardianto (2014:8) rekrutmen diartikan sebagai suatu proses untuk mendapatkan calon karyawan yang memiliki kemampuan yang sesuai dengan kualifikasi dan kebutuhan suatu organisasi/perusahaan. Rekrutmen menurut Marwansyah (2012:106) adalah proses menarik orangorang atau pelamar yang mempunyai minat dan kualifikasi yang tepat untuk mengisi posisi atau jabatan tertentu. Sedangkan menurut Mila Badriyah (2015:88) rekrutmen adalah proses mendapatkan sejumlah calon tenaga kerja yang berkualitas untuk jabatan/pekerjaan utama dilingkungan perusahaan dalam rangka menerima sesorang dalam perusahaan.

Menurut Mardianto (2014:41) indikator-indikator dari variabel proses rekrutmen terdiri dari:1) Dasar Penarikan, yang harus berpedoman kepada spesifikasi pekerjaan yang telah ditentukan untuk menduduki jabatantersebut; 2) Sumber-Sumber Penarikan, dibutuhkan untuk mencari calon karyawan yang sesuai dengan spesifikasi yang dibutuhkan, sumber dilakukan secara internal maupun eksternal; 3) Metode Penarikan, sangat berpengaruh besar untuk mendapatkan banyaknya lamaran dari calon karyawan yang sesuai untukperusahaan; dan 4) Kendala-Kendala Penarikan, agar proses penarikan berhasil, perusahaan perlu menyadari beberapa kendala yang bersumber dari organisasi, pelaksanaan penarikan, dan lingkungan.

\section{Seleksi}

Menurut Malayu S.P Hasibuan (2013:47) mengemukakan bahwa seleksi adalah suatu kegiatan pemilihan dan penentuan pelamar yang diterima atau ditolak untuk menjadi karyawanperusahaan. Menurut I Komang Ardana (2012:69) seleksi tenaga kerja adalah suatu kegiatan untuk memenuhi syaratsyarat yang telah ditetapkan oleh perusahaan. Sedangkan menurut Siagian (2014:131) seleksi merupakan serangkaian langkah spesifik untuk menentukan pelamar mana yang akan diterima danpelamar mana yang akan ditolak. Proses seleksi dimulai dari penerimaan lamaran dan berakhir dengan keputusan terhadap lamaran tersebut.

Indikator seleksi karyawan menurut Malayu S.P Hasibuan (2013:54-56) terdiri dari: 1) Umur, harus mendapatkan perhatian karena akan mempengaruhi kondisi fisik, mental, kemampuan kerja, dan tanggung jawab seseorang; 2) Keahlian, digolongkan menjadi tiga macam, yaitu: technical skill (keahlian yang dimiliki oleh pegawai), human skill (keahlian yang dimiliki oleh sub pimpinan), conceptual skill (keahlian yang dimiliki oleh pucuk pimpinan); 3) Kesehatan fisik, penting untuk menduduki suatu jabatan. Tidak mungkin seseorang dapat menyelesaikan tugas-tugasnya jika sering sakit; 4) Pendidikan, merupakan suatu indikator yang mencerminkan kemampuan seseorang untuk dapat menyelesaikan suatu pekerjaan. Dengan latar belakang pendidikan pula seseorang akan dianggap mampu menduduki suatu jabatan tertentu; 5) Jenis Kelamin, harus diperhatikan berdasarkan sifat pekerjaan, waktu mengerjakan, dan peraturan perburuhan; 6) Tampang (physical appearance) adalah keseluruhan penampilan dan kerapihan diri seseorang yang tampak dari luar. Tampang hanyalah kualifikasi tambahan. Artinya untuk jabatan tertentu tampang akan turut membantu keberhasilan seseorang dalam melaksanakan tugasnya; 7) Bakat (mental aptitude) perlu mendapat perhatian, karena orang yang berbakat lebih cepat berkembang dan mudah menangkap pengarahan yang diberikan. Biasanya orang yang berbakat lebih kreatif mengembangkan dirinya; dan 8) Pengalaman Kerja, hendaknya menjadi pertimbangan dalam seleksi. Orang yang berpengalaman merupakan calon karyawan yang telah siap 
pakai.

\section{Hipotesis}

Hipotesis yang akan diuji pada penelitian ini yaitu:

H1: Terdapat pengaruh yang signifikan rekrutmen karyawan terhadap kinerja karyawan pada PT. Telkom Akses JakartaBarat.

$\mathrm{H}$ 2: Terdapat pengaruh yang signifikan seleksi karyawan terhadap kinerja karyawan pada PT. Telkom Akses JakartaBarat.

H3: Terdapat pengaruh yang signifikan rekrutmen dan seleksi secara bersama-sama terhadap kinerja karyawan pada PT. Telkom Akses JakartaBarat.

\section{METODE}

Metode penelitian yang digunakan dalam penelitian ini yaitu deskriptif kualitatif. Penelitian ini dilakukan pada PT. Telkom Akses Jakarta Barat yang berada di Letjen S. Parman St No.Kav 8, Tomang, Grogol petamburan, West Jakarta City, Jakarta 11440. Populasi yang dijadikan objek dalam penelitian ini adalah seluruh karyawan yang bekerja pada PT. Telkom Akses Jakarta Barat dengan jumlah karyawan sebanyak 240 orang. Adapun jumlah sampel yang didapat dengan menggunakan rumus Slovin didapat sebanyak 70 karyawan.

Metode analisis yang digunakan dalam penelitian meliputi: uji validitas, uji reliabilitas, uji asumsi klasik (normalitas, uji multikolinieritas, uji heteroskedastisitas), analisis regresi linier berganda, uji koefisien determinasi, uji t dan uji F.

\section{HASIL DAN PEMBAHASAN}

\section{Uji Normalitas}

Uji normalitas dilakukan untuk mengetahui apakah populasi data berdistribusi normal, uji normalitas untuk setiap variabel dilakukan dengan melihat titik sebaran data pada gambar grafik P-P Plot. Data-data dari variabel dapat dikatakan terdistribusi normal, jika data atau titik menyebar berada pada disekitar garis diagonal dan mengikuti arah garis diagonal, sebaliknya data dikatakan tidak terdistribusi normal,jika data atau titik menyebar jauh dari arah garis atau tidak mengikuti garis diagonal.

Tabel 2. Uji Normalitas Kolmogorov-Smirnov Test

\begin{tabular}{|c|c|c|}
\hline \multicolumn{3}{|r|}{ Unstandardized Residual } \\
\hline $\mathrm{N}$ & & 70 \\
\hline \multirow[t]{2}{*}{ Normal Parameters ${ }^{\mathrm{a}, \mathrm{b}}$} & Mean & .0000000 \\
\hline & Std. Deviation & 2.61695605 \\
\hline \multirow[t]{3}{*}{ Most Extreme Differences } & Absolute & .071 \\
\hline & Positive & .061 \\
\hline & Negative & -.071 \\
\hline Test Statistic & & .071 \\
\hline Asymp. Sig. (2-tailed) & & $.200^{\mathrm{c}, \mathrm{d}}$ \\
\hline \multicolumn{3}{|c|}{$\begin{array}{l}\text { a. Test distribution is Normal. } \\
\text { b. Calculated from data. } \\
\text { c. Lilliefors Significance Correction. } \\
\text { d. This is a lower bound of the true significance. } \\
\text { Sumber: Data Yang Diolah SPSS, } 2018\end{array}$} \\
\hline
\end{tabular}

Berdasarkan hasil uji normalitas diketahui nilai signifikansi 0,200>0,05 maka dapat disimpulkan bahwa nilairesidual berdistribusi normal.

\section{Uji Heteroskedastisitas}

Pengujian heteroskedastisitas dimaksud-kan untuk menguji apakah dalam sebuah model regresi terjadi ketidaksamaan varians residual menggunakan uji Glesjer dimana hasil uji ini dapat dilihat 
apakah dalam model regresi terjadi ketidaksamaan varian dari suatu residual pengamatan ke pengematan lain. Hasil uji heteroskedastisitas seperti yang ditunjukkan pada tabel berikut:

Tabel 3. Hasil Uji Heteroskedastisitas dengan Glejser

Coefficients $^{\mathrm{a}}$

\begin{tabular}{|c|c|c|c|c|c|}
\hline \multirow[t]{2}{*}{ Model } & \multicolumn{2}{|c|}{ Unstandardized Coefficients } & $\begin{array}{l}\text { Standardized } \\
\text { Coefficients }\end{array}$ & $\mathrm{t}$ & Sig. \\
\hline & B & Std. Error & Beta & & \\
\hline (Constant) & 2,400 & 1,264 & & 1,900 &, 062 \\
\hline 1 Proses Rekrutmen (X1) & 0,15 & 0,035 & 0,53 & ,436 & 665 \\
\hline Seleksi (X2 &,- 032 & 0,36 &,- 109 & -892 & ,376 \\
\hline
\end{tabular}

a. Dependent Variable: Abs_Res

Berdasarkan hasil pengujian pada tabel diatas, glejser test model pada variabel motivasi kerja dan kompensasi diperoleh nilai probability signifikan (Sig.) lebih besar dari 0,05. Artinya pada regression model tidak ada gangguan heteroskesdastisitas.

\section{Uji Multikolinieritas}

Multikolinieritas menujukkan adanya hubungan antara variable bebas dalam model. Model yang baik tidak menunjukkan adanya gejala Multikolinieritas. Pendeteksian ada atau tidaknya multikolinieritas dilakukan dengan melihat nilai VIF apabila nilai $\mathrm{VIF}<10$, maka model bebas dari Multikolinieritas. Berikut adalah nilai VIF yang dihasilkan.

Tabel 4. Uji Multikolinieritas

Coefficiens $^{\mathrm{a}}$

\begin{tabular}{lccc}
\hline Variabel & Tolerance & VIF & \multicolumn{1}{c}{ Keterangan } \\
\hline Proses Rekrutmen ( X1) & 0,993 & 1,007 & Non Multikoliniearitas \\
\hline Seleksi (X2) & 0,993 & 1,007 & Non Multikoliniearitas \\
\hline \multicolumn{2}{c}{ Sumber: Data Yang Diolah SPSS, 2018} & &
\end{tabular}

Dilihat dari uji Multikolinieritas pada tabel, coefficients nilai VIF 1,007 $<10$ maka tidak terjadi Multikolinieritas antar rekrutmen dan seleksi karyawan.

\section{Analisis Regresi}

Berikut hasil analisis regresi linier berganda:

Tabel 5. Hasil dari Regresi Linier Berganda

Coefficients $^{\mathrm{a}}$

\begin{tabular}{|c|c|c|c|c|c|}
\hline \multirow[b]{2}{*}{ Model } & \multicolumn{2}{|c|}{$\begin{array}{l}\text { Unstandardized } \\
\text { Coefficients }\end{array}$} & \multirow{2}{*}{$\begin{array}{c}\begin{array}{c}\text { Standardized } \\
\text { Coefficients }\end{array} \\
\text { Beta }\end{array}$} & \multirow[b]{2}{*}{$\mathrm{t}$} & \multirow[b]{2}{*}{ Sig. } \\
\hline & B & Std. Error & & & \\
\hline 1 (Constant) & 11.747 & 2.070 & & 5.675 & .000 \\
\hline Proses Rekrutmen ( X1) & .156 & .058 & .126 & 2.692 & .009 \\
\hline Seleksi (X2) & 1.136 & .059 & .905 & 19.351 & .000 \\
\hline
\end{tabular}

a. Dependent Variable: Kinerja (Y)

Berdasarkan data dalam tabel di atas, diperoleh persamaan regresi $\mathrm{Y}=11,747+0,156 \mathrm{X} 1+1,136 \mathrm{X} 2$. Persamaan regresi tersebut mempunyai arti:

1. Nilai constant sebesar 11,747 , artinya kinerja karyawan walaupun tanpa dipengaruhi oleh rekrutmen dan seleksi sudah mempunyai pengaruh 11,747.

2. Pengaruh variabel Rekrutmen terhadap Kinerja karyawan adalah positif. Artinya semakin baik rekrutmen, maka kinerja karyawan akan meningkat 0,156 .

3. Pengaruh variabel seleksi terhadap kinerja karyawan adalah positif. Artinya semakin tinggi tinggi rekrutmen maka kinerja karyawan akan meningkat sebesar 1,135. 


\section{Pengujian Hipotesis}

Uji t

Pengujian secara parsial (Uji t) digunakan untuk mengetahui apakah variabel Rekrutmen dan seleksi secara parsial berpengaruh terhadap Kinerja Karyawan. Uji dilakukan dengan membandingkan nilai t hitung dengan $t$ tabel dengan ketentuan sebagai berikut:

1. Apabila propabilitas signifikasi $>0,05$ maka Ho diterima dan Ha ditolak.

2. Apabila propabilitas signifikasi $<0,05$ maka Ho ditolak dan Ha diterima.

Tabel 6. Hasil Uji Signifikansi parsial (Uji t)

\begin{tabular}{|c|c|c|c|c|c|}
\hline \multirow[b]{3}{*}{ Model } & \multicolumn{2}{|c|}{ Coefficients $\mathrm{s}^{\mathrm{a}}$} & \multirow[b]{2}{*}{$\begin{array}{l}\text { Standardized } \\
\text { Coefficients }\end{array}$} & \multirow[b]{3}{*}{$\mathrm{t}$} & \multirow[b]{3}{*}{ Sig } \\
\hline & $\begin{array}{r}\text { Unsta } \\
\text { Coe }\end{array}$ & $\begin{array}{l}\text { dized } \\
\text { ents }\end{array}$ & & & \\
\hline & $\mathrm{B}$ & Std. Error & Beta & & \\
\hline 1 (Constant) & 11.747 & 2.070 & & 5.675 & .000 \\
\hline Proses Rekrutmen ( X1) & .156 & .058 & .126 & 2.692 & .009 \\
\hline Seleksi (X2) & 1.136 & .059 & .905 & 19.351 & .000 \\
\hline
\end{tabular}

a. Dependent Variable: Kinerja (Y)

Sumber: Data Yang Diolah SPSS, 2018

Dari tabel di atas dapat dilihat bahwa masing masing variabel bebas memiliki pengaruh yang berbeda beda terhadap variabel terkait. Dari pengujian tersebut dapat diketahui bahwa nilai signifikansi data variabel $\mathrm{X}$ yang diteliti terbukti memiliki pengaruh yang signifikan terhadap variabel $\mathrm{Y}$. Hal ini disebabkan karena 2 variabel $X$ nilai signifikan $<0,05$. Selain dengan melihat nilai signifikasinya, pengujian secara parsial dapat dilihat dari nilai thitung yang lebih besar dari nilai $t$ tabel.

\section{Uji F}

Uji F ini bertujuan untuk menguji apakah terdapat pengaruh secara bersama sama (simultan) dari masing masing variabel indenpen terhadap variabel dependen.

Tabel 7. Uji Simultan

ANOVA $^{a}$

\begin{tabular}{clccccc}
\hline & Model & Sum of Squares & df & Mean Square & F & Sig. \\
\hline \multirow{3}{*}{1} & Regression & 2770.828 & 2 & 1385.414 & 196.432 & $.000^{\mathrm{b}}$ \\
\cline { 2 - 7 } & Residual & 472.544 & 67 & 7.053 & & \\
\cline { 2 - 7 } & Total & 3243.371 & 69 & & & \\
\hline
\end{tabular}

a. Dependent Variable: Variabel Y

b. Predictors: (Constant), Variabel X2, Variabel X1

Sumber: Data Yang Diolah SPSS, 2018

Berdasarkan tabel 7 dapat dilihat nilai signifikasi adalah 0,000 atau lebih kecil dari 0,05 maka Ho ditolak dan Ha diterima, maka dapat dinyatakan bahwa rekrutem dan seleksi secara bersama-sama berpengaruh terhadap kinerja karyawan.

\section{Uji Koefisien Determinasi $\left(\mathbf{R}^{2}\right)$}

Besarnya kontribusi variabel independen mempengaruhi variabel dependen dapat diketahui dari nilai koefisien determinasi.

Tabel 8. Hasil Uji Koefisien Determinasi Model Summary ${ }^{\mathbf{b}}$

\begin{tabular}{llrrr}
\hline Model & R & R Square & Adjusted R Square & Std. Error of the Estimate \\
\hline 1 & $.924^{\mathrm{a}}$ & .854 & .850 & 2.656 \\
\hline
\end{tabular}

a. Predictors: (Constant), Selesi (X2), Proses Rekrutmen (X1)

b. Dependent Variable: Kinerja (Y)

Sumber : Data Yang Diolah SPSS , 2018

Dari tabel diatas diperolek koefisien determinasi atau $\mathrm{R}$ square adalah 0,854 artinya 85,4\% variabel terkait yaitu kinerja karyawan (Y) variasinya dapat dijelaskan oleh variabel Rekrutmen (X1) dan seleksi (X2). 


\section{SIMPULAN}

Berdasarkan penelitian yang telah dilakukan maka dapat diperoleh kesimpulan sebagai berikut:

Rekrutmen berpengaruh positif dan signifikan terhadap kinerja pegawai PT. Telkom Akses dengan hasiluji t-hitung 2.692 dan nilai signifikasi $0,009<0,05$.

Seleksi karyawan berpengaruh positif dan signifikan terhadap kinerja pegawai PT. Telkom Akses dengan hasil uji t-hitung 19.351 dan nilai signifikasi $0,000<0,05$.

Rekrutmen dan seleksi karyawan secara bersama sama berpengaruh positif dan signifikan terhadap kinerja pegawai PT. Telkom Akses. Hal ini dapat dilihat dari nilai si uji F yaitu 196.432, dengan nilai signifikasi 0,000 lebih kecil dari 0,05 .

Disarankan bagi peneliti selanjutnya dapat mengembangkan variabel-variabel lain seperti beban kerja, stress kerja, dan kompensasi sehingga dapat sebagai referensi untuk meneliti variabel yang belum pernah dilakukan maupun menggunakan objek penelitian lainnya dan dengan penambahan jumlah responden di objek penelitian yang berbeda.

\section{DAFTAR PUSTAKA}

Afandi, P. (2018). Manajemen Sumber Daya Manusia. Cetakan Pertama. Riau: ZANAFA PUBLISHING.

Athoillah, Anton. (2016). Dasar-dasar Manajemen. Bandung: CV Pustaka Setia.

Chukwuma, E.M., \& Obiefuna, O. (2014). Effect of Motivation on Employee Productivity: A Study of Manufacturing Companies in Nnewi. Journal of Managerial Studies and Research 2 (7).

Danang, Sunyoto. (2016). Manajemen Sumber Daya Manusia. Jakarta: PT Buku Seru.

Edy, Sutrisno. (2016). Manajemen Sumber Daya Manusia. Cetakan ke-8. Jakarta

:Prenada Media Group.

Edison, Emron. Yohny anwar, Imas komariyah. (2016). Manajemen Sumber Daya Manusia. Bandung: Alfabeta.

Fahmi, Irham. (2016). Pengantar Manajemen Sumber Daya Manusia: Konsep dan Kinerja. Jakarta: Mitra Wacana Media.

Hamali, Arif Yusuf. (2016). Pemahaman Manajemen Sumberdaya Mausia. Yogyakata: Center for Academic Publishing Servive

Ferdinand, Augusty. (2016). Metode Penelitian Manajemen. BP Universitas Diponegoro. Semarang.

Foster. Bill. (2014). Pembinaan Untuk Peningkatan Kinerja Karyawan. PPM: Jakarta.

Ghozali, Imam. (2016). Structural Equation Modeling, Metode Alternatif dengan Partial Least Square $(P L S)$. Edisi 4.Semarang : Badan Penerbit Universitas Diponegoro.

Ghozali, Imam. (2016). Konsep, Teknik, Aplikasi Menggunakan Smart PLS 3.0 Untuk Penelitian Empiris. BP Undip. Semarang.

Ghozali, Imam. (2016). Aplikasi Analisis Multivariete Dengan Program IBM SPSS 23 (Edisi 8). Cetakan ke VIII. Semarang : Badan Penerbit Universitas Diponegoro.

Hamali, Arif Yusuf. (2016). Pemahaman manajemen sumber daya manusia. Yogyakarta: CAPS.

Hasibuan, M. S. (2016). Manajemen Sumber Daya Manusia. Jakarta: PT Bumi Aksara.

Mangkunegara, A. P. (2017). Manajemen Sumber Daya Manusia Perusahaan. Bandung: PT.Remaja Rosdakarya.

Manullang, M. (2015), Dasar-dasar Manajemen, Yogykarta: Gadjah Mada University Press.

Marwansyah. 2016. Manajemen Sumber Daya Manusia. Edisi Dua. Cetakan keempat. Bandung: Alfabeta CV.

Pamela, A.O., \& Oloko (2015). Effect of motivation on employee performance of commercial banks in kenya: A case study of Kenya Commercial Bank in Migori County. Journal of Human Resource Studies 5 (2).

Priatna, Cepi. (2015). Perilaku Organisasi. PT. Remaja Rosdakarya, Bandung.

Sinambela, D. P. (2016). Manajemen Sumber Daya Manusia. Jakarta: PT Bumi Aksara.

Sedarmayanti. (2016). Manajemen Sumber Daya Manusia, Reformasi Birokrasi dan Manajemen Pegawai Negeri Sipil (cetakan kelima). Bandung : PT Refika Aditama.

Sinambela, Lijan Poltak. (2017). Manajemen Sumber Daya Manusia, Cetakan ke-2. Jakarta: Bumi 
Aksara.

Sugiyono, Prof Dr;. (2016). Metode Penelitian Pendekatan Kuantitatif, Kualitatif, dan R\& D. Bandung: Alfabeta.

Sugiyono. (2016). Metode Penelitian Kuantitatif, Kualitatif dan R\&D, Cetakan ke-24. Bandung: Alfabeta.

Sujarweni, V. Wiratna. (2016). Metode Penelitian: Lengkap, Praktis, dan Mudah Dipahami. Yogyakarta: Pustaka Baru Press.

Sutikno, sobry M. (2014). Pemimpin Dan Gaya Kepemimpinan, Edisi Pertama Lombok: Holistica.

Widodo, S. E. (2016). Manajemen Pengembangan Sumber Daya Manusia. Yogyakarta: Pustaka Pelajar.

Widodo, Sri. (2016). Manajemen Sumber Daya Manusia: Teori, Perencanaan Strategi, Isu-isu Utama dan Globalisasi, Manggu Media, Bandung. 